\title{
Food intake, nutritional status and gastrointestinal symptoms in children with cerebral palsy
}

\author{
Deise Cristina Oliva CARAMICO-FAVERO ${ }^{1}$, Zelita Caldeira Ferreira GUEDES ${ }^{2}$ and Mauro Batista de MORAIS ${ }^{3}$
}

Received 8/6/2018 Accepted 7/12/2018

\begin{abstract}
Background - Cerebral palsy may be associated with comorbidities such as undernutrition, impaired growth and gastrointestinal symptoms. Children with cerebral palsy exhibit eating problems due to the effect on the anatomical and functional structures involved in the eating function resulting in malnutrition. Objective - The aim of this study was to investigate the association between food intake, nutritional status and gastrointestinal symptoms in children with cerebral palsy. Methods - Cross-sectional study that included 40 children with cerebral palsy (35 with spastic tetraparetic form and 5 with non-spastic choreoathetoid form of cerebral palsy, all requiring wheelchairs or bedridden) aged from 4 to 10 years. The dietary assessment with the parents was performed using the usual household food intake inquiry. Anthropometric data were collected. Gastrointestinal symptoms associated with deglutition disorders, gastroesophageal reflux and chronic constipation were also recorded. Results - The median of height-for-age Z-score (-4.05) was lower $(P<0.05)$ than the median of weight-for-age $(-3.29)$ and weight-for-height $(-0.94)$. There was no statistical difference between weight-forage and weight-for-height Z-scores. Three patients with cerebral palsy (7.5\%) exhibited mild anemia, with normal ferritin levels in two. Symptoms of dysphagia, gastroesophageal reflux, and constipation were found in $82.5 \%(\mathrm{n}=33), 40.0 \%(\mathrm{n}=16)$, and $60.0 \%(\mathrm{n}=24)$ of the sample, respectively. The patients with symptoms of dysphagia exhibited lower daily energy (1280.2 $\pm 454.8 \mathrm{Kcal}$ vs $1890.3 \pm 847.1 \mathrm{Kcal}, P=0.009)$, carbohydrate (median: $170.9 \mathrm{~g}$ vs $234.5 \mathrm{~g}, P=0.023)$ and fluid intake $(483.1 \pm 294.9 \mathrm{~mL}$ vs $992.9 \pm 292.2 \mathrm{~mL}, P=0.001)$. The patients with symptoms of gastrointestinal reflux exhibited greater daily fluid intake $(720.0 \pm 362.9 \mathrm{~mL})$ than the patients without symptoms of gastroesophageal reflux $(483.7 \pm 320.0 \mathrm{~mL}, P=0.042)$ and a greater height-for-age deficit (Z-score: $-4.9 \pm 1.7$ vs $3.7 \pm 1.5, P=0.033$ ). The patients with symptoms of constipation exhibited lower daily dietary fiber $(9.2 \pm 4.3 \mathrm{~g}$ vs $12.3 \pm 4.3 \mathrm{~g}, P=0.031)$ and fluid $(456.5 \pm 283.1 \mathrm{~mL}$ vs $741.1 \pm 379.2 \mathrm{~mL}, P=0.013)$ intake. Conclusion - Children with cerebral palsy exhibited wide variability in food intake which may partially account for their severe impaired growth and malnutrition. Symptoms of dysphagia, gastroesophageal reflux, and constipation are associated with different food intake patterns. Therefore, nutritional intervention should be tailored considering the gastrointestinal symptoms and nutritional status.
\end{abstract}

HEADINGS - Cerebral palsy. Gastrointestinal diseases. Nutritional status. Deglutition disorders. Gastroesophageal reflux. Constipation.

\section{INTRODUCTION}

Cerebral palsy is a chronic non-progressive encephalopathy that is caused by various agents and presents with heterogeneous clinical manifestations ${ }^{(1)}$. It may be associated with comorbidities such as undernutrition ( $46 \%$ to $90 \%$ of the patients) ${ }^{(2)}$, impaired growth, mental retardation, epileptic seizures, communication disorders, visual and auditory defects ${ }^{(3)}$, and gastrointestinal symptoms, including dysphagia, gastroesophageal reflux, and constipation ${ }^{(4,5)}$. Food intake is one of the factors that determine malnutrition ${ }^{(4)}$. Oropharyngeal dysphagia due to motor dysfunction ${ }^{(5-7)}$ may reduce the food intake of patients, with consequent malnutrition, pulmonary aspiration, respiratory infection, and chronic lung disease ${ }^{(8-9)}$. Gastroesophageal reflux in cerebral palsy is associated with severe complications, such as esophagitis and esophageal dysphagia, and also with reduced food intake ${ }^{(3,7)}$. As for constipation, it is believed that alterations in the neural modulation are associated with reduced colonic motility ${ }^{(10)}$. Other factors may also contribute to the development of constipation, such as severe skeletal deformities, spasm, use of anticonvulsants ${ }^{(1)}$, low levels of physical activity, and a low-fiber $\operatorname{diet}^{(7,12)}$.

Children with cerebral palsy exhibit eating problems due to the effect on the anatomical and functional structures involved in the eating function ${ }^{(3)}$, resulting in reduced energy and nutrient intake and in consequent malnutrition ${ }^{(12)}$. As a function of malnutrition, the body fat reserves become depleted, the muscle mass is reduced, and immune dysfunction occurs, with consequent increased risk of respiratory and urinary tract infections ${ }^{(13,14)}$.

No study published up to the present time has sought to associate nutritional status with food intake and the presence of gastrointestinal symptoms in cerebral palsy ${ }^{(15,16)}$. Therefore, the aim of this study was to investigate the correlation of food intake and nutritional status with the presence of gastrointestinal symptoms in children with severe cerebral palsy.

\section{Case series and methods}

This cross-sectional study was approved by the Ethics Committee of the São Paulo School of Medicine, Federal University of São

Declared conflict of interest of all authors: none

Disclosure of funding: no funding received

1 Universidade Federal de São Paulo, Programa de Pós-Graduação em Nutrição, São Paulo, SP, Brasil. ${ }^{2}$ Universidade Federal de São Paulo, Departamento de Fonoaudiologia, São Paulo, SP, Brasil. ${ }^{3}$ Universidade Federal de São Paulo, Escola Paulista de Medicina, Disciplina de Gastroenterologia Pediátrica, São Paulo, SP, Brasil.

Corresponding author: Mauro Batista de Morais. Orcid: https://orcid.org/0000-0003-4014-5549. E-mail: mbmorais@osite.com.br 
Paulo (Universidade Federal de São Paulo). Data were collected at the outpatient clinic of Our Home Spiritualist Center - André Luiz Houses (Centro Espírita Nosso Lar-Casas André Luiz), Guarulhos, and at Saint Francis Children's Home (Lar Escola São Francisco), São Paulo, Brazil. The children's guardians and institutional representatives were asked to sign an informed consent form.

The sample of this study was of convenience, which comprised 40 children with cerebral palsy, $23(57.5 \%)$ male and $17(42.5 \%)$ female. The patients socioeconomic level was established based on the classification formulated by the Brazilian Association of Market Research Companies (Associação Brasileira de Empresas de Pesquisa - ABEP) ${ }^{(17)}$.

All of the patients had severe cerebral palsy, requiring wheelchairs or bedridden. The age varied from 4 to 10 years that was the selected range for inclusion in the study. All of the patients who met the inclusion criteria and had medical appointments on the days when the study was conducted were invited to participate in the study. According to the Oxford Feeding Study II classification ${ }^{(18)}$, $87.5 \%(35 / 40)$ of the patients had the spastic tetraparetic cerebral palsy and $12.5 \%(5 / 40)$ had the non-spastic choreoathetoid form of cerebral palsy.

Information was registered in a form that included personal, socioeconomic, and anthropometric data, clinical history, gastrointestinal symptoms, feeding route, characteristics of oral motor function, and dietary survey.

The dietary assessment with the parents was performed using the usual household food intake inquiry. The dietary data was collected by one of the authors (Caramico-Favero DCO) who is an experienced nutritionist. Utensils and utensils album images have been used and sipped over the table (homemade measures). Posteriorly homemade measuring was converted to grams and milliliters. Hydric ingestion was calculated from the liquids intake of the diet (water, coconut water, juices, milk, carbonated drinks, jellies and teas). The water used for cleaning the enteral tube or gastrostomy was also computed. The type of enteral diet was also registered (homemade blended, commercial formula or both homemade and commercial). Information about noncommercial enteral feeding was collected. Nutrition calculations were performed using the NutWin Software for Support for Decision-Making in Nutrition version 2.5 by the Federal University of São Paulo ${ }^{(19)}$.

The food intake values were compared to the references in Dietary Reference Intake (DRI) for the following parameters: Estimated Energy Requirements (EER); Estimated Average Requirement (EAR) of energy; Recommended Dietary Allowance (RDA) and Tolerable Upper Intake Level (UL) of carbohydrates and proteins ${ }^{(20)}$. Fiber intake was assessed based on the American Health Foundation's recommendation, according to which the minimum daily fiber intake (in grams) is equal to the child's age (in years) plus five ${ }^{(21)}$.

To assess the participants' nutritional status, their body weight was measured, and their height was estimated. The body weight was assessed using a Toledo ${ }^{\circledR}$ (São Bernardo do Campo, São Paulo, Brazil) $500-\mathrm{kg}$ capacity scale with a $100 \mathrm{-g}$ precision platform. This scale allowed the weighing of children on wheelchairs as needed. The children's current weight was calculated by subtracting the wheelchair weight from the combined child-wheelchair weight; the children were weighed wearing a minimum of clothing and without diapers. In the remaining cases, as the sample characteristically comprised children who cannot stand up by themselves, they were held by an adult and weighed, and their current weight was calculated by subtracting the adult's weight from the combined child-adult weight. The children's height was estimated based on the tibia length ${ }^{(22)}$.

The anthropometric parameters weight-for-age, height-for-age, and weight-for-height were analyzed based on Z-scores relative to the reference values established by the World Health Organization (WHO). Values two standard deviations below the corresponding $\mathrm{Z}$-score were considered to be indicative of nutritional deficit ${ }^{(23,24)}$.

To assess the children's hemoglobin and ferritin levels, blood samples were collected by puncture of a forearm vein, which was performed by a duly trained professional at America Diagnosis Laboratory (Laboratório Diagnósticos da América, Barueri, São Paulo, Brazil). Sample analysis was performed using a Pentra ABX automated analyzer, Horiba Medical (Kyoto, Japan). The diagnosis of anemia and iron deficiency was based on comparing the measured blood hemoglobin and ferritin levels to the reference values formulated by $\mathrm{WHO}^{(25)}$.

Symptoms suggestive of dysphagia, gastroesophageal reflux, or constipation were recorded in the patients' individual forms.

The symptoms of dysphagia were evaluated by speech therapists based on reported occurrence of cough, drooling, or choking; orofacial motor features registered during the study in ad hoc form; utensils used for feeding; and consistency of the food consumed ${ }^{(26)}$. The presence of nausea, vomiting, and regurgitation was considered symptoms of gastroesophageal reflux ${ }^{(27)}$. Constipation was defined as pain and/or strain to pass stools combined with fragmented and hard or cylindrical stools with diameter larger than a hotdog sausage with cracks in the surface, and/or two or fewer defecations per week. Having only two or fewer isolated bowel movements per week was considered to be indicative of constipation. Patients who did not meet any of those criteria but used laxatives were also characterized as having constipation. This definition was adapted from previous studies that assessed constipation in children with neurological diseases ${ }^{(10,28,29)}$. The symptoms of gastroesophageal reflux and constipation were assessed by a gastroenterologist.

The results were analyzed by means of parametric and non-parametric statistical tests depending on the distribution of the variables and are described together with the results. Analysis was performed using the software SigmaStat version 3.5. (Systat Software, San Jose, California, USA) ${ }^{(30)}$ and Epi-Info version 3.2.2 (Atlanta, GA, USA $)^{(31)}$. The value set to reject the null hypothesis was 0.05 or $5 \%$.

\section{RESULTS}

The sample comprised 40 children with cerebral palsy with mean age of $6.7 \pm 2.4$ years old, of whom $33(82.5 \%)$ were fed by the oral route, five $(12.5 \%)$ via a gastrostomy tube, and two $(5.0 \%)$ by the oral route combined with a nasogastric or gastrostomy tube.

According to Friedman's test followed by Dunn's multiple comparison test, the height-for-age Z-score of the 40 children with cerebral palsy (median $=-4.05 ; 25$ th and 75 th percentiles: -5.30 and -2.89) exhibited a greater deficit $(P<0.05)$ than weight-for-age (median $=-3.29 ; 25$ th and 75 th percentiles: -3.95 and -2.28 ) and weight-for-height (median $=-0.94 ; 25$ th and 75 th percentiles: -2.06 and 0.12). Weight-for-age and weight-for-height did not reach statistical significant difference $(P>0.05)$.

TABLE 1 describes the data on daily carbohydrate, protein intake, distributed according to the RDA and EAR for age and gender. The protein and carbohydrate intake was above the RDA in $92.5 \%(37 / 40)$ and $85.0 \%(34 / 40)$ of the participants, respectively. 
TABLE 1. Carbohydrate and protein intake according to Estimated Average Requirement (EAR), Recommended Dietary Allowance (RDA), and Tolerable Upper Intake Level (UL) of children with cerebral palsy.

\begin{tabular}{|c|c|c|c|c|c|}
\hline Nutrient & $<2 \mathrm{SD}$ of EAR & From $-2 \mathrm{SD}$ of EAR to EAR & Within EAR and RDA & $>\mathrm{RDA}$ & $>\mathrm{UL}$ \\
\hline Carbohydrates* (g/day) & $1(2.5 \%)$ & $1(2.5 \%)$ & $4(10.0 \%)$ & $34(85.0 \%)$ & - \\
\hline Protein* (g/day) & - & - & $3(7.5 \%)$ & $37(92.5 \%)$ & - \\
\hline
\end{tabular}

*Mean intake (standard-deviation) of carbohydrates and protein were, respectively, $199.6 \pm 85.3$ and $48.6 \pm 17.9 \mathrm{~g}$.

In $30 \%(12 / 40)$ of the sample, the energy intake was less than $90 \%$ of the EER; in $20 \%(8 / 40)$ of the sample it was $91 \%$ to $120 \%$ of the EER; and in 50\% (20/40) it was more than $120 \%$ of the EER.

Approximately $57.5 \%$ of the sample $(n=23)$ consumed less than the minimum daily fiber intake recommended by the American Health Foundation (age in years +5 ).

Regarding the prevalence of gastrointestinal symptoms, $82.5 \%$ (33/40) of the sample exhibited symptoms of dysphagia, $40.0 \%$ (16/40) symptoms suggestive of gastroesophageal reflux, and $60.0 \%$ (24/40) clinical evidence of constipation.

TABLE 2 compares the anthropometric and dietetic data, nutritional indexes and the intake of energy, macronutrients, fiber, and fluids as a function of the presence or absence of symptoms of dysphagia. The mean energy intake was significantly lower among the children with clinical signs of dysphagia $(P=0.009)$. In regard to the macronutrients, the children with dysphagia exhibited a greater intake of carbohydrates and protein and lower intake of fat, but only the carbohydrate intake exhibited a significant difference $(P=0.023)$. Fluid intake was significantly lower among the children with dysphagia $(P=0.001)$.

TABLE 2. Comparison of anthropometric nutritional parameters and energy, macronutrient, fiber, and fluid intake between children with cerebral palsy with or without dysphagia.

\begin{tabular}{|c|c|c|c|}
\hline \multirow{2}{*}{ Variable } & \multicolumn{2}{|c|}{ Dysphagia } & \multirow{2}{*}{$P$} \\
\hline & Yes $(n=33)$ & No $(n=7)$ & \\
\hline Height-for age Z-score* & $-4.4 \pm 1.6$ & $-4.3 \pm 1.5$ & 0.833 \\
\hline $\begin{array}{l}\text { Weight-for-height } \\
\text { Z-score* }\end{array}$ & $-1.0 \pm 1.7$ & $-0.6 \pm 2.2$ & 0.504 \\
\hline Weight-for-age Z-score* & $-3.2 \pm 1.0$ & $-3.0 \pm 1.4$ & 0.637 \\
\hline \multicolumn{4}{|l|}{ Dietary intake } \\
\hline Energy $(\mathrm{kcal} / \text { day })^{*}$ & $1280.2 \pm 454.8$ & $1890.3 \pm 847.1$ & 0.009 \\
\hline $\begin{array}{l}\text { Carbohydrates } \\
(\mathrm{g} / \text { day)** }\end{array}$ & $\begin{array}{c}170.9 \\
(137.3 ; 214.3)\end{array}$ & $\begin{array}{c}234.5 \\
(187.1 ; 327.2)\end{array}$ & 0.023 \\
\hline Protein (g/day)* & $46.0 \pm 17.1$ & $60.5 \pm 17.9$ & 0.051 \\
\hline Fat (g/day)* & $41.4 \pm 21.1$ & $61.3 \pm 34.1$ & 0.050 \\
\hline Fiber (g/day)* & $10.0 \pm 4.4$ & $12.6 \pm 4.8$ & 0.160 \\
\hline Iron $* *$ & $9.0(6.1 ; 13.3)$ & $12,0(7.3 ; 16.2)$ & 0.200 \\
\hline Fluids (mL/day)* & $483.1 \pm 294.9$ & $992.9 \pm 292.2$ & 0.001 \\
\hline
\end{tabular}

*Mean and standard deviation, Student's t-test; **Median and 25th and 75th percentiles, Mann-Whitney test.
TABLE 3 compares the anthropometric and dietary indicators as a function of the presence or absence of clinical manifestations compatible with gastroesophageal reflux disease. The children with signs and symptoms suggestive of gastroesophageal reflux disease exhibited greater fluid intake $(P=0.042)$.

TABLE 3. Comparison of anthropometric nutritional parameters and daily energy, macronutrient, fiber, and fluid intake between children with cerebral palsy with or without clinical manifestations of gastroesophageal reflux.

\begin{tabular}{|c|c|c|c|}
\hline \multirow{2}{*}{ Variable } & \multicolumn{2}{|c|}{ Gastroesophageal reflux } & \multirow{2}{*}{$P$} \\
\hline & Yes $(n=16)$ & No $(n=24)$ & \\
\hline Height-for age Z-score* & $-4.9 \pm 1.7$ & $-3.7 \pm 1.5$ & 0.033 \\
\hline $\begin{array}{l}\text { Weight-for-height } \\
\text { Z-score* }\end{array}$ & $-1.1 \pm 1.7$ & $0.9 \pm 1.8$ & 0.751 \\
\hline Weight-for-age Z-score* & $-3.3 \pm 1.1$ & $-3.0 \pm 1.0$ & 0.514 \\
\hline \multicolumn{4}{|l|}{ Intake } \\
\hline Energy $(\mathrm{kcal} / \mathrm{day})^{*}$ & $1276.9 \pm 406.8$ & $1460.4 \pm 668.2$ & 0.332 \\
\hline Carbohydrates (g/day)* & $226.4 \pm 111.6$ & $181.7 \pm 58.2$ & 0.105 \\
\hline Protein (g/day)* & $51.8 \pm 19.3$ & $46.5 \pm 16.9$ & 0.357 \\
\hline Fat $(\mathrm{g} / \mathrm{day}) * *$ & $46.1(30.2 ; 68.1)$ & $35.5(28.9 ; 48.1)$ & 0.199 \\
\hline Fiber $(\mathrm{g} / \text { day })^{*}$ & $8.7 \pm 4.4$ & $11.6 \pm 4.3$ & 0.052 \\
\hline $\operatorname{Iron}(\mathrm{mg} / \mathrm{dia}) * *$ & $8.0(5.6 ; 11.7)$ & $11.9(6.7 ; 15.8)$ & 0.071 \\
\hline Fluids (mL/day)* & $720.0 \pm 362.9$ & $483.7 \pm 320.0$ & 0.042 \\
\hline
\end{tabular}

*Mean and standard deviation, Student's t-test; **Median and 25th and 75th percentiles, Mann-Whitney test.

TABLE 4 compares the nutritional and dietary data as a function of the presence or absence of clinical evidences of constipation. The children with symptoms of constipation exhibited significantly lower daily intake of fiber $(P=0.031)$ and fluids $(P=0.013)$.

As TABLES 2, 3 and 4 show, the anthropometric parameters did not differ between the children with or without gastrointestinal symptoms, except, for patients with gastroesophageal symptoms who presented lower height-for-age Z-score.

The hemoglobin and ferritin levels shown that three male participants $(7.5 \%)$ exhibited mild anemia, with normal ferritin levels in two. No child exhibited ferritin reduction not accompanied by a decreased hemoglobin level. The mean iron intake of the sample was $11.0 \pm 6.0 \mathrm{mg} /$ daily. 
TABLE 4. Comparison of anthropometric nutritional parameters and daily energy, macronutrient, fiber and fluid intake between children with cerebral palsy with or without constipation.

\begin{tabular}{|c|c|c|c|}
\hline \multirow{2}{*}{ Variable } & \multicolumn{2}{|c|}{ Constipation } & \multirow{2}{*}{$P$} \\
\hline & Yes $(n=24)$ & No $(n=16)$ & \\
\hline Height-for-age Z-score* & $-4.4 \pm 1.6$ & $-3.9 \pm 1.7$ & 0.337 \\
\hline $\begin{array}{l}\text { Weight-for-height } \\
\text { Z-score* }\end{array}$ & $-0.9 \pm 1.5$ & $-1.0 \pm 2.1$ & 0.881 \\
\hline Weight-for-age Z-score* & $-3.2 \pm 1.0$ & $-3.1 \pm 1.2$ & 0.927 \\
\hline \multicolumn{4}{|l|}{ Intake } \\
\hline Energy (kcal/day)* & $1488.8 \pm 656.1$ & $1234.3 \pm 412.4$ & 0.176 \\
\hline $\begin{array}{l}\text { Carbohydrates } \\
(\mathrm{g} / \text { day)** }\end{array}$ & $\begin{array}{c}195.6 \\
(158.6 ; 250.8)\end{array}$ & $\begin{array}{c}166.6 \\
(131.8 ; 197.0)\end{array}$ & 0.095 \\
\hline Protein $(\mathrm{g} /$ day)** & $\begin{array}{c}45.6 \\
(35.6 ; 67.1)\end{array}$ & $\begin{array}{c}40.2 \\
(34.9 ; 57.3)\end{array}$ & 0.448 \\
\hline Fat $(\mathrm{g} / \text { day })^{* *}$ & $\begin{array}{c}46.8 \\
(29.5 ; 58.0)\end{array}$ & $\begin{array}{c}33.9 \\
(27.5 ; 45.9)\end{array}$ & 0.275 \\
\hline Fiber (g/day)* & $9.2 \pm 4.3$ & $12.3 \pm 4.3$ & 0.031 \\
\hline Iron & $8.0(5.6 ; 12.9)$ & $11.9(8.1 ; 15.0)$ & 0.062 \\
\hline Fluids (mL/day)* & $456.5 \pm 283.1$ & $741.1 \pm 379.2$ & 0.013 \\
\hline
\end{tabular}

*Mean and standard deviation, Student's t-test; **Median and 25 th and 75 th percentiles, Mann-Whitney test.

\section{DISCUSSION}

The results of this study show that children with cerebral palsy often exhibit inadequate food intake, severe anthropometric deficits, and a high frequency of gastrointestinal symptoms associated with certain diet characteristics.

Malnutrition and impaired growth are a common in children with cerebral palsy due to several factors, some of which are related to $\operatorname{diet}^{(3,16,32,33)}$. Although inadequate intake of energy, protein, essential fatty acids, vitamins, and minerals is considered to be the main cause of these conditions ${ }^{(15,34)}$ few studies have assessed the food intake of children with cerebral palsy. A study conducted in Greece compared the energy intake of 16 children with cerebral palsy and 16 children without neurologic abnormalities (control group) and found it to be inadequate in both groups ${ }^{(15)}$. In addition to inadequate energy intake, muscle tone, level of physical activity, and the presence of involuntary motions may contribute to the incidence of malnutrition found in children with cerebral palsy by increasing their daily energy requirements ${ }^{(34)}$.

A study conducted in Norway on 221 children with mental deficiency found that the presence of orofacial dysfunction is associated with reduced daily energy intake ${ }^{(35)}$. It should be observed that the reference values used in this study were based on the nutrient intake of children who did not present cerebral palsy and thus may not be fully appropriate for children with cerebral palsy. The EAR values correspond to the median distribution of the nutrient requirements of healthy individuals of the same gender and age range and meet the needs of $50 \%$ of the corresponding population $^{(20)}$. In children with spastic paralysis, the muscles are hypertonic, which increases their energy requirements ${ }^{(5)}$. In addition, in such children, orofacial motor dysfunction interferes with sucking, chewing, and swallowing. The prevalence oforopharyngeal dysphagia varies from 16 to $99 \%{ }^{(32)}$. Affection of the oral phase of swallowing is characterized by inability to control the food in the mouth due to problems with sealing the lips, loss of oral reflexes and of the motion of the anterior and dorsal parts of the tongue, and difficulties in chewing. Individuals with cerebral palsy have difficulty closing the lips while swallowing, which contributes to the food bolus escaping the mouth, aggravating malnutrition, and hinders the assessment of effective food intake ${ }^{(5,32)}$. In this study, clinical symptoms of dysphagia were found in most of the participants (33/40) who exhibited lower energy intake (TABLE 2) than the ones without evidence of dysphagia. A Brazilian study carried out in Santos (São Paulo, Brazil) included 90 children with quadriplegic cerebral palsy aged between 2 and 13 years showed high prevalence difficult to chewing $(41 \%)$ and swallow $(12.8 \%)^{(36)}$.

In regard to macronutrient distribution, the intake of carbohydrates and protein was over the RDA in $85.0 \%$ (34/40) and $92.5 \%$ (37/40) of the sample, respectively, as shown in TABLE 1 . The carbohydrate intake was significantly higher among the children without dysphagia (TABLE 2). A study conducted in Greece ${ }^{(15)}$ with children with cerebral palsy up to 10 years old found that carbohydrates represented $47 \%$, fat $36 \%$, and protein $17 \%$ of the energy intake, and that this distribution was adequate in the case of carbohydrates and proteins but slightly above the recommended intake in the case of fat according to the Acceptable Macronutrient Distribution Range (AMDR), which indicates the ideal distribution of energy provided by each macronutrient relative to the total energy intake ${ }^{(20)}$. A previous study in Brazil found low consumption of carbohydrates $(52 \%)$, adequate intake of protein $(53 \%)$ and high intake of lipids $(43 \%)^{(36)}$. In the Queensland, Australia, a study verified that non-ambulant, tube-fed cerebral palsy patients had significantly lower protein intakes compared to orally fed children ${ }^{(37)}$. There were no other differences in macronutrient intake between children with cerebral palsy and the control group.

The low prevalence of iron deficiency anemia found in this study is noteworthy. Only a single child with cerebral palsy had reduced hemoglobin and ferritin. The two patients presenting reduced hemoglobin did not have low serum ferritin levels.

Low fluid intake combined with insufficient dietary fiber intake may contribute to the development of constipation ${ }^{(5,7)}$. Approximately $60 \%$ of the sample in this study exhibited constipation, which agrees with the reports in the literature ${ }^{(5,12,38)}$. The average daily dietary fiber intake was lower among the participants with constipation (TABLE 4). A similar association was found with fluid intake, i.e., the amount of water consumed by the children with constipation was lower than the amount consumed by the children without constipation (TABLE 4). The reason for the lower dietary fiber intake exhibited by individuals with cerebral palsy may be that they consume foods with a low degree of consistency ${ }^{(5,12)}$. A Brazilian group of children with cerebral palsy also had low daily intake of fruits and vegetables (sources of dietary fiber) and liquids (less than three cups of $200 \mathrm{~mL} /$ daily). In this study, 14 of 39 children with quadriplegic cerebral palsy presented less than 3 evacuations per week ${ }^{(36)}$. In addition to the dietary factors, cerebral palsy is associated with intestinal motility disorders characterized by increased transit time in the transverse colon and rectum ${ }^{(7,38)}$, as well as with changes in recto-anal function that result in a longer duration of the anal inhibitory reflex ${ }^{(5)}$.

Gasrtointestinal sympoms of gastroesophageal reflux disease were found in $40.0 \%$ of the participants in this study. The children with evidence of gastroesophageal reflux exhibited lower heightfor-age in addition to greater fluid intake, most likely because softer foods are less uncomfortable to swallow (TABLE 3). 
The sample size might represent a limitation of this study. However, the frequency of gastrointestinal symptoms and the dietary data obtained were so clinically relevant that the number of patients was sufficient to obtain statistically significant differences in several parameters. A second limitation might be the decision to evaluate study only gastrointestinal symptoms. However, the Rome III diagnostic criteria for gastrointestinal functional disorders in patients without neurologic abnormalities recommends that the diagnosis should be established taking into account the gastrointestinal symptoms ${ }^{(39)}$. In addition, we considered unethical to perform diagnostic tests for dysphagia, gastrointestinal reflux disease/esophagitis (exposing the participants to radiation and sedation) specifically for this study.

\section{CONCLUSION}

This study found a wide variation in the results of the dietary survey. Whereas the protein intake was excessive in a large number of cases. The participants exhibited significant anthropometric deficits, which may be partially related to dietary factors. However, it is important to note that the nutritional deficit exhibited by patients with cerebral palsy is multifactorial. Gastrointestinal symptoms are a frequent occurrence among individuals with cerebral palsy. The patients with constipation exhibit lower fluid and dietary fiber intake; energy consumption is reduced in the patients with symptoms of dysphagia; and the individuals with symptoms of gastroesophageal reflux consume greater amounts of fluids. As a conclusion, within the context of multi-professional care provided to patients with cerebral palsy, nutritional interventions should be individualized as a function of the particular needs of each patient.

\section{ACKNOWLEDGEMENTS}

We thank the patients and families who participated in the study as well as the institutions (Casas André Luiz and Lar Escola São Francisco) where the study was conducted. We thank American Journal Experts which provided writing services on behalf of Brazilian National Research Council (Conselho Nacional de Pesquisa).

\section{Authors' contribution}

All the authors participated in the conception and study design, interpretation of results and the writing and revising the final version of the manuscript. Caramico Favero DCO was responsable for data collection. All authors read and approve the final manuscript.

Caramico-Favero DCO, Guedes ZCF, Morais MB. Ingestão alimentar, estado nutricional e sintomas gastrintestinais em crianças com paralisia cerebral. Arq Gastroenterol. 2018;55(4):352-7.

RESUMO - Contexto - Paralisia cerebral pode estar associada com comorbidades como desnutrição, déficit de crescimento e sintomas gastrintestinais. Os problemas alimentares na paralisia cerebral podem ser secundários a anormalidades anatômicas e funcionais que interferem no processo de alimentação. Objetivo - O objetivo deste estudo foi avaliar a associação entre ingestão alimentar, estado nutricional e sintomas gastrintestinais em crianças com paralisia cerebral. Métodos - Estudo transversal que incluiu 40 crianças com paralisia cerebral (35 com tetraparesia espástica e 5 com coreoatetose não-espástica) com idade entre 4 e 10 anos. Todos os pacientes permaneciam exclusivamente na cama ou dependiam de cadeiras de rodas. Foi utilizado o inquérito dos alimentos consumidos habitualmente em casa que foi respondido pelos pais. Foram mensurados os dados antropométricos. Sintomas gastrintestinais associados com distúrbios da deglutição, refluxo gastroesofágico e constipação intestinal crônica foram obtidos. Resultados - A mediana do escore $\mathrm{Z}$ da estatura para idade $(-4,05)$ foi menor $(P<0,05)$ do que a mediana de peso-idade $(-3,29)$ e peso-estatura $(-0,94)$. Não se observou diferença entre os escores $Z$ de peso-idade e peso-estatura. Três pacientes com paralisia cerebral $(7,5 \%)$ apresentavam anemia leve com valor normal de ferritina. Sintomas de disfagia, refluxo gastroesofágico e constipação intestinal ocorreram, respectivamente, em 82,5\% (n=33), 40,0\% (n=16) e $60,0 \%(\mathrm{n}=24)$ dos pacientes estudados. Os pacientes com sintomas de disfagia apresentaram menor ingestão energética diária $(1280,2 \pm 454,8 \mathrm{Kcal}$ vs $1890,3 \pm 847,1 \mathrm{Kcal} ; P=0,009)$, de carboidratos (mediana: $170,9 \mathrm{~g}$ vs $234,5 \mathrm{~g} ; P=0,023)$ e de líquidos $(483,1 \pm 294.9 \mathrm{~mL}$ vs $992,9 \pm 292,2 \mathrm{~mL} ; P=0,001)$. Os pacientes com sintomas de refluxo gastroesofágico apresentaram maior ingestão diária de líquidos $(720,0 \pm 362,9 \mathrm{~mL}) \mathrm{em}$ relação aos pacientes sem este tipo de manifestação clínica $(483,7 \pm 320,0 \mathrm{~mL} ; P=0.042)$ além de maior déficit de estatura-idade (escore $\mathrm{Z}:-4,9 \pm 1,7$ vs $3,7 \pm 1,5 ; P=0,033)$. Os pacientes com sintomas de constipação intestinal apresentaram menor ingestão diária de fibra alimentar $(9,2 \pm 4,3 \mathrm{~g}$ vs $12,3 \pm 4,3 \mathrm{~g} ; P=0.031)$ e líqui$\operatorname{dos}(456,5 \pm 283,1 \mathrm{~mL}$ vs $741,1 \pm 379,2 \mathrm{~mL} ; P=0,013)$. Conclusão - Crianças com paralisia cerebral apresentam uma grande variabilidade na ingestão alimentar que pode, pelo menos em parte, constituir um fator de agravo para o déficit de crescimento. Sintoma de disfagia, refluxo gastroesofágico e constipação intestinal associaram-se com diferentes padrões de ingestão alimentar. Portanto, a intervenção nutricional deve ser individualizada levando em consideração os sintomas gastrintestinais e o estado nutricional.

DESCRITORES - Paralisia cerebral. Gastroenteropatias. Estado nutricional. Transtornos de deglutição. Refluxo gastroesofágico. Constipação intestinal. 


\section{REFERENCES}

1. Diament A. Encefalopatias crônicas na infância (paralisia cerebral) [Chronic encephalopathies in childhood (cerebral palsy)]. In: Diament A, Cypel S. Neurologia infantil [Pediatric neurology]. 4a ed. vol. 1. São Paulo: Atheneu; 2005.p. 901-20.

2. Penagini F, Mameli C, Fabiano V, Brunetti D, Dilillo D, Zuccotti GV. Dietary intakes and nutritional issues in neurologically impaired children. Nutrients. 2015;7:9400-15.

3. Fung EB, Samson-Fang MD, Stallings MD, Conaway M, Liptak MD, Henderson $\mathrm{RC}$, et al. Feeding dysfunction is associated with poor growth and health status in children with cerebral palsy. J Am Diet Assoc. 2002,102:361-73.

4. Colver A, Fairhurst C, Pharoah POD. Cerebral palsy. Lancet. 2014;383:1240-9.

5. Araújo LA, Silva LR, Mendes FA. Digestive tract neural control and gastrointestinal disorders in cerebral palsy. J Ped (Rio J). 2012;88:455-64

6. Calis E, Veugelers R, Sheppard JJ, Tibboel D, Evenhuis HM, Penning C. Dysphagia in children with severe generalized cerebral palsy and intellectual disability. Dev Med Child Neurol. 2008;50:625-30.

7. Chong SKF. Gastrointestinal problems in the handicapped child. Curr Opin Pediatr. 2001;13:441-6.

8. Ferluga ED, Shate NA, Krishnaswami S, Mcpheeters ML. Surgical intervention for feeding and nutrition difficulties in cerebral palsy: a systematic review. Dev Med Child Neurol. 2014, 56:31-43.

9. Pruit DW, Tsai T. Common medical comorbidities associated with cerebral palsy. Phis Med Rehabil Clin N Am. 2009;20:453-67.

10. Veugelers R, Benninga MA, Calis EA, Willemsen SP, Evenhuis H, Tibboel D, et al. Prevalence and clinical presentation of constipation in children with severe generalized cerebral palsy. Dev Med Child Neurol. 2010, 52:e216-21.

11. Almeida IR. [Anorectal manometry in children with cerebral palsy and chronic constipation (Masters Thesis)]. São Paulo: Universidade Federal de São Paulo; 2007.

12. Böhmer CJ, Taminiau JAJ, Klinkenberg-Knol EC, Meuwissen SG. The prevalence of constipation in institutionalized people with intellectual disability. J Intellect Disabil Res 2001;45:212-8.

13. Sullivan PB. Nutrition and growth in children with cerebral palsy: setting the scene. Eur J Clin Nutr. 2013;67(S3-S4).

14. Soylu OB, Unalp A, Uran N, Dizdarer G, Ozgonul FO, Conku A, et al. Effect of nutritional support in children with spastic quadriplegia. Pediatr Neurol. 2008;39:330-4

15. Grammatikopoulou MG, Daskalou E, Tsigga M. Diet, feeding practices, and anthropometry of children and adolescents with cerebral palsy and their siblings. Nutrition. 2009;25:620-6.

16. Vernon-Roberts A, Wells J, Grant H, Alder N, Vadamalayan B, Eltumi M, et al. Gastrostomy feeding in cerebral palsy: enough and no more. Dev Med Child Neurol. 2010;52:1099-105.

17. ABEP - Associação Brasileira de Empresas de Pesquisa. [Criterion of economic classification in Brazil]. São Paulo: ABEP: 2003. [Internet]. [Accessed 2006 July 08]. Available from: http://www.abep.org/.

18. Sullivan PB, Juszczak E, Lambert BR, Rose M, Ford-Adams ME, Johnson A. Impact of feeding problems on nutritional intake and growth: Oxford feeding study II. Dev Med Child Neurol 2002;44:461-7.

19. Anção MS, Cuppari L, Tudisco LS, Draibe AS, Sigulem D. Sistema de apoio à decisão em nutrição-versão 2.5 [Support system for decision-making in nutrition - version 2.5]. Centro de informática em saúde da Universidade Federal de São Paulo - Escola Paulista de Medicina; 1993.

20. National Research Council (NRC). Dietary Reference Intakes for energy, carbohydrate, fiber, fat, fatty acids, cholesterol, protein, and amino acids. Washington (DC): National Academy Press; 2002. [Internet]. Available from: htpp://www. iom.edu/Object.File/Master/21/372/0.pdf
21. Willians CL, Bollella M, Wynder EL. A new recommendation for dietary fiber in childhood. Pediatrics 1995;96:985:8.

22. Stevenson RD. Use of segmental measures to estimate stature in children with cerebral palsy. Arch Pediatr Adolesc Med. 1995;149:658-62.

23. World Health Organization (WHO). Child growth standards: methods and development: length/height-for-age, weight-for-age, weight-for-length, weight-for-height and body mass index-for-age. Geneva, Switzerland: WHO, 2006.

24. World Health Organization (WHO). Onis M, Onyango AW, Borghi E, Siyam A, Nishida C, Siemann J. Development of a WHO growth reference for schoolaged children and adolescents. Bulletin of the World Health Organization, p. 660-7, 2007.

25. Gleason G, Scrimshaw NS. An overview of the functional significance of iron deficiency. In: Kraemer K, Zimmermann MB. Nutrition Anemia. Switzerland: Sigght and Life, 2007. p. 45-57.

26. Furkim AM, Behlau S, Weckx LLM. [Clinical and videofluoroscopic evaluation of deglutition in children with spastic tetraparetic spastic cerebral palsy]. Arq Neuropsiquiatr. 2003;61:611-6.

27. Campanozzi A, Guglielmo C, Miele E, Romano A, Scuccimarra G, Del Giudice $\mathrm{E}$, et al. Impact of malnutrition on gastrointestinal disorders and gross motor abilities in children with cerebral palsy. Brain \& Development. 2007;29:25-9.

28. Schhwartzman F, Vítolo MR, Schhwartzman JS, Morais MB. Eating practices, nutritional status and constipation in patients with Rett syndrome. Arq Gastroenterol. 2008;45:284-9.

29. Rasquin A, Di Lorenzo C, Forbes D, Guiraldes E, Hyams J, Staiano A, Walker LS. Childhood functional gastrointestinal disorders: Child/Adolescent. Gastroenterology. 2006;130:1527-37.

30. Sigma Stat 2.0 for Windows (computer progam). I st ed. Point Richmond: Systat Software, 1995.

31. Dean AG, Arner TG, Sunki GG, et al. Epi Info TM, a database and statistics program for public health professionals (computer program). Version 3.3.2 Atlanta (GO): Centers for Disease Control and Prevention, Atlanta; 2002.

32. Benfer KA, Weir KA, Bell KL, Ware RS, Davies PSW, Boydi RN. Longitudinal cohort protocol study of oropharyngeal dysphagia: relationships to gross motor attainment, growth and nutritional status in preschool children with cerebral palsy. BMJ Open. 2012;0:e001460.

33. Andrew MJ, Sullivan PB. Growth in cerebral palsy. Nutr Clin Pract. 2010. 25:357-6.

34. Marchand V, Motil KJ. Nutrition support for neurologically impaired children: a clinical report of the North American Society for Pediatric Gastroenterology, Hepatology, and Nutrition. J Pediatr Gastroenterol Nutr. 2006;43:123.

35. Thommessen M, Riis G, Kase BF, Larsen S, Heiberg A. Energy and nutrient intakes of disabled children: do feeding problems make a difference? J Am Diet Assoc. 1991;91:1522-5.

36. Lopes PAC, Amancio OMS, Araújo RFC, Vitalle MSS, Braga JAP. Food pattern and nutrition status of children with cerebral palsy. Rev Paul Pediatr. 2013;31:344-9.

37. Walker JL, Bell KL, Stebenson RD, WEIR KA, Boyd RN, Davies PSW. Relationships between dietary intake and body composition according to gross motor functional ability in preschool-aged children with cerebral palsy. Ann Nutr Metab. 2012;61:349-57.

38. Del Guildice E, Staiano A, Guglielmo C, Romano A, Florimonte L, Miele E, et al. Gastrointestinal manifestations in children with cerebral palsy. Brain \& Development. 1999;21:307-11

39. Drossman DA. The functional gastrointestinal disorders and the Rome III process. Gastroenterology. 2006;130:1377-90. 